\title{
Three forms of identification and a letter from God
}

\author{
Stan Burridge uses his personal experience and his work with homeless and ex-homeless people \\ to offer support to doctors who want to help
}

\section{Stan Burridge}

When I was street homeless, the challenge was getting to see a general practitioner. So many obstacles were in the way-no address, out of area, no proof of who I was. It was as if I needed three forms of identification and a letter from God just to get past the receptionist.

Surgery doors closed in my face, and excuse after excuse was given as to why I couldn't see the doctor. I was sent to other surgeries, dragging myself and my possessions halfway across town only to be sent away once I got there.

\section{Same old story}

On the rare occasion when I managed to slip in under the radar to see the doctor, I never mentioned that I was sleeping rough. I am sure that the smelly clothes, dirty fingernails, and grubby rucksack were giveaways, but I was in so I kept my mouth shut. I wanted my problems sorted there and then. I would have a long list of mostly minor health problems, and I expected the GP to cover them all. I wanted one swish of a magic wand, the quick fix treatment. The story always ended the same way, a few minutes later I was being ushered out of the surgery with a prescription in hand, and the main cause of my problems-homelessness-was never talked about.

Often I'd be back within a few days, armed with another list of health problems, and once again, I would leave with a fresh batch of drugs. What I needed was someone to talk to about being homeless and the problems that went with that, and I needed someone to do a bit of hand holding.

\section{The change}

I was lucky. I ended up finding, by word of mouth, a GP whom the homeless people in that area went to see. The service was set up for homeless people so there was no problem getting in or being registered. From there, my life changed-slowly, but it changed.

I used my journey to help others, and I am now the Experts by Experience project lead for the homeless healthcare charity, Pathway. I bring together current and former homeless and marginalised people to talk about homelessness and how the healthcare system could be shaped to handle some of the challenges they face. In collaboration with the Healthy London Partnership, we have produced a video and e-learning package about GP registration for homeless people, which is backed by the Care Quality Commission (see Further resources box). The package has been circulated to all GP surgeries in London.

Specialist surgeries are needed desperately, but staff should be working to help patients get back into mainstream GP services. Easier said than done of course, but information on how to achieve this can be found in the Further resources box below. If those services become better at responding to the needs of homeless people—not just people on the streets, but people who have been homeless, and those at risk of homelessness-then the number of homeless people using hospital emergency departments might drop.

\section{My advice}

The package will help reception staff understand the rights and needs of homeless patients, but it won't help them understand all the problems of homelessness. This is my advice for doctors working with homeless people.

1.Homeless people will present with lists of things they want you to do. Manage expectations. Be clear about what you can do now, and plan the rest.

2.Learn about local services, tap into some of the resources that are available (see Further resources box).

3.Take some continuing professional development training that has homeless health as its main theme (see Further resources box). It's best if this includes people with lived experience.

4.If you can tell your patients where to get advice on benefits and how to apply for them it will help them a lot.

5.Listen to your patients.

My life is different now from when I was street homeless because I was able to deal with my health problems. I have a home, a salaried job with a pension, I go on exotic holidays, and I have an excellent social life. It is a long way from the time 
when I could not see a GP and my life was spiralling out of control.
Competing interests: I have read and understood BMJ policy on declaration of interests and declare the following: none.

Published by the BMJ Publishing Group Limited. For permission to use (where not already granted under a licence) please go to http://group.bmj.com/group/rights-licensing/ permissions 


\section{What you need to know}

- You can make a difference to the long term health of homeless patients so don't be afraid to ask if they are living on the street

- Check that your reception staff are not putting up obstacles to care and ensure that they know the "rules" around what is needed for registration

- You don't need to do it all yourself; find out about local services that can support people who have lost their home

\section{Further resources}

NHS Healthy London Partnership. E-learning: helping people who are homeless register at GP practices. www.healthylondon.org/ homeless/e-learning

Pathway. Standards for GP receptionists in primary care. www.pathway.org.uk/wp-content/uploads/2017/02/GP-reception-standardsfor-primary-care-v10.pdf

Pathway. Homelessness and general practice. www.pathway.org.uk/training-and-events/learning/gp/

UK Government. Benefits. www.gov.uk/browse/benefits.

Crisis. Health and wellbeing. www.crisis.org.uk/ending-homelessness/health-and-wellbeing/ Shelter. Housing advice. http://england. shelter.org.uk/get_advice

NHS Healthy London Partnership. Healthcare and people who are homeless. Commissioning guidance for London. 2016. www. healthylondon.org/sites/default/files/Commissioning\%20guidance\%20for\%20London\%20-\%20Homeless\%2Ohealth.pdf

\section{Education into practice}

- Have you and your colleagues had training on working with homeless patients, including the NHS rules on rights of registration? If not, how might you go about getting it?

- Are you familiar with local organisations that support homeless people?

- How might you manage the needs and expectations of patients with multiple health and social problems?

- What might you do differently as a result of reading this article? 